\title{
Plans to step up bioterrorism research via the NIH...
}

Prompted by the recent anthrax scare in the US, the Bush administration is to enhance bioterrorism research programs at the National Institute of Allergy and Infectious Diseases (NIAID).

The initiative arose, in part, from "a recent outpouring of ideas from concerned academic and industrial scientists on ways to combat potential agents of bioterrorism," Health and Human Services secretary, Tommy Thompson, said in a statement, adding that the intention is for the NIAID to be able to put many of those new ideas into practice.

NIAID director, Anthony Fauci (see page 10), says, "Our offices have been deluged with calls from scientists who want to help. At scientific meetings and conferences I am often approached by researchers with promising ideas and a desire to contribute to the fight against bioterrorism."

NIAID is the main beneficiary of National Institutes of Health (NIH) funding for bioterrorism and in FY01 received $\$ 36$ million for this area of investigation from the total $\$ 47$ million that NIH earmarked for bioterrorism. Prior to 11 September, the President's FY02 budget requested an increase to $\$ 93$ million for $\mathrm{NIH}$ bioterrorism research, of which $\$ 81.6$ million would go to the NIAID. Those sums are now expected to rise further as a result of the terrorist attacks.

Among the areas outlined in the new initiative are increased research into 'high-priority Category A' biological diseases, such as anthrax, botulism, plague, smallpox, tularemia and viral hemorrhagic fevers. More research into anthrax vaccines, including what the NIAID views as one of the most promising types, a recombinant protective antigen vaccine. Increased research into drug development and diagnostics for bioterrorism pathogens, and more technology grants to enable scientists to either purchase new genetic sequencing equipment or to collaborate with other scientists who have the technology.

At the heart of many of the programs is a drive to encourage partnerships between academia and pharmaceutical and biotechnology companies. A quicker response to funding applica- tions for bioterrorism research is also promised. The NIAID hopes to reduce decision-making time from the current 9 or 10 months to 6 months after it receives the application. A web page

\section{....and at the CDC}

US government laboratories specializing in infectious disease research are operating on heightened alert in the wake of the anthrax attacks. In the midst of this raised awareness, the country's Surgeon General, David Satcher, has castigated working conditions at America's principal public health agency, the Centers for Disease Control and Prevention (CDC).

At a press briefing in Boston last month, Satcher-who was himself director of the CDC from 1993 to 1998-said the nation should be "ashamed" of the CDC's out-of-date and poorly equipped labs and that the entire public health system urgently needs the major infusion of cash that would be forthcoming from a 15 November bill introduced by Senators Edward Kennedy (Massachusetts-D) and Bill Frist (Tennesse-R).

As if to emphasize the material problems facing CDC researchers, a power failure put its main lab in Atlanta out of commission for 15 hours in the early days of the anthrax scare, and on 5 December it was claimed that confirmatory diagnoses of new cases of West Nile virus were suspended because the CDC was over-stretched with anthrax testing.

The CDC is at the center of a web of federal public health agencies. C.J. Peters, former Head of the Special Pathogens Branch at the CDC and now director of a new Bioterrorism Institute at the University of Texas Medical Branch in Galveston, says, "In the case of anthrax, the patient diagnostic sam- listing new bioterrorism research funding opportunities can be seen at http://www.niaid.nih.gov/dmid/bio terrorism/.

Marlene Cimons, Washington, D.C.

ples, nose and environmental swabs should have been sent to [other laboratories]. Only the most important agents, such as the spore powder, should have been tested by CDC."

Peters says that one reason the work was not triaged out is that, "State health departments are under-equipped, and we as a nation are not ready to deal with bioterrorism." CDC spokesperson Lisa Swenarski insists that only one West Nile sample was delayed and this did not affect the patient's treatment.

Of the CDC's $\$ 4.1$ billion FY01 budget, $\$ 182$ million is assigned to bioterrorism research. HIV/AIDS and tuberculosis tops the list with $\$ 1$ billion in funding. The Kennedy-Frist bill (Bioterrorism Preparedness Act of 2001 (S 1715)) would provide $\$ 3.2$ billion to fund a variety of measures related to terrorism, including food protection, transportation and vaccine production. In addition, it proposes to increase funding for state and local public health agencies by $\$ 50$ million to $\$ 420 \mathrm{mil}$ lion.

Richard Feachem, director of the Institute for Global Health, a joint institute of UC Berkeley, UC San Francisco and Stanford University, comments that even though the CDC is "the envy of the world" in terms of public health institutions, it mirrors the imbalance in public health funding worldwide: total healthcare in the US costs $\$ 1.3$ trillion yet the CDC's $\$ 4$ billion budget is only a minuscule proportion of that.

Potter Wickware, San Francisco

\section{Faculty demands AIDS drugs for all}

South African medical education leaders have broken their silence and issued a public statement directly attacking their government's policy on AIDS. In the statement, released early December, the Faculty of Health Sciences at the University of
Witwatersrand (UW) in Johannesburg called on the government to acknowledge that HIV causes AIDS and immediately enact measures to respond to the crisis. South African universities have not undertaken such a public role in protesting government policy since 